\title{
Prevalence of Sickle Cell Among Patients Attending Immunogenetic Diagnostic Laboratory Akwanga, Nasarawa State Nigeria
}

\author{
Raymond Tersoo Ada*, Patrick Ije Ode, Stephen Oche Onah \\ Department of Biological Sciences, Faculty of Science, Benue State University, Makurdi, Nigeria \\ Email address: \\ tersooada@gmail.com (R. T. Ada), patrickode15@gmail.com (P. I. Ode), onahstephen9@gmail.com (S. O. Onah) \\ *Corresponding author
}

To cite this article:

Raymond Tersoo Ada, Patrick Ije Ode, Stephen Oche Onah. Prevalence of Sickle Cell Among Patients Attending Immunogenetic Diagnostic Laboratory Akwanga, Nasarawa State Nigeria. International Journal of Immunology. Vol. 6, No. 1, 2018, pp. 17-24.

doi: $10.11648 /$ j.iji.20180601.13

Received: September 22, 2017; Accepted: October 10, 2017; Published: March 7, 2018

\begin{abstract}
Sickle Cell Disease is an inherited blood disease caused by abnormal haemoglobin. This study was conducted to determine the prevalence of sickle cell among patients attending Immunogenetic Diagnostic Laboratory Akwanga, Nassarawa State. Aseptically, $2 \mathrm{mls}$ of blood was collected from the dorsal vein of the patients into Ethylene Diamine Tetra-acetic Acid (EDTA) bottles and mixed gently to prevent clotting. A small quantity of haemolysate from each of the subjects was placed on a cellulose acetate membrane and carefully introduced into the Electrophoretic tank containing Tris-EDTA buffer at pH 8.6. Electrophoretic separation was then allowed to take place for 15-20 minutes at an Electromotive Force (EMF) of 160V. A total of three hundred and eighty three (283) patients consisting of $195(50.9 \%)$ males and $188(49.1 \%)$ females were sampled in the study. Questionnaires were administered to the patients involved in the study as to obtain demographic and other relevant information regarding the research. The prevalence of the HbAA, $\mathrm{HbAS}$ and $\mathrm{HbSS}$ were $72.32 \%, 25.06 \%$ and $2.60 \%$ respectively. Statistically, there was a significant difference $(p<0.05)$ between gender, age, locality and the prevalence of the Sickle Cell as observed in this study. The prevalence recorded for HbSS in this study is low compared to the value range of 1$10 \%$ expected for Nigeria. Based on the findings from this study, it is recommended that genetic counseling policies should be developed to enable prospective couples make decisions aimed at reducing the sickling gene pool in our population.
\end{abstract}

Keywords: Prevalence, Sickle Cell, Akwanga

\section{Introduction}

One of the biggest health challenges facing the human race is Sickle Cell Disease (SCD). Sickle Cell Disease is an inherited blood disorder caused by abnormal hemoglobin [1]. The disease limits the oxygenating role of hemoglobin, resulting in the damaging or the "sickling" of the red blood cells [2]. This disorder affects all parts of the human body and differs widely among individuals [3]. In 1910, Dr. James Herrick, a Chicago physician, was the first American to formally report and identify elongated, sickle-shaped hemoglobin in an anemic Grenadian student's blood smear. Herrick coined the now familiar term "sickle cell" [4]. The sickle shaped red blood cells described by Herrick caused several complications including chronic anemia, vaso- occlusive pain episodes, ischemic organ damage, infections, small stature and delayed puberty [2]. Sickle cell disease affects millions of people throughout the world and it is found to be the most common blood disorder among families whose ancestors came from Sub-Saharan Africa, South America, Cuba, Central America, Saudi Arabia, India and the Mediterranean regions [1]. In Africa, sickle cell disease has been a prevalent disorder for many generations now [5].

According to the World Health Organization, sickle cell disorder contributes to $5 \%$ of under-five deaths in the African continent; more than $9 \%$ of such deaths occur in West Africa and up to $16 \%$ of under-five deaths in individual West African countries. In Nigeria, about one hundred and fifty thousand $(150,000)$ children are born each year with sickle cell disease and about $2-3 \%$ of Nigerians live with the 
disease while $25-30 \%$ of Nigerians carry the gene that can give rise to Sickle Cell Disease (SCD) [6]. It is estimated that by the year 2025 , a total number of 50,000 children born in Nigeria will be affected with sickle cell disorder and this poses a great concern [7].

In order to address this situation, many research studies have recommended prevention strategies such as newborn screening and genetic counseling as effective approaches in reducing the prevalence of SCD [1, 8]. Many studies also recommended prevention by way of increased awareness about the disease and dissemination of carrier status, thereby enabling at-risk populations to make informed decisions regarding child bearing $[1,9,10]$. More so, providing education about SCD may be an effective way to reduce the transmission rate and empower individuals most at risk to understand the medical conditions associated with SCD, such as frequent painful episodes known as crisis, stroke, renal failure and many other medical problems that ultimately result in premature mortality [11 - 13]. Health education about the disease may also empower individuals to make educated decisions related to receiving genetic screening, getting genetic counseling and discussing SCD transmission with their partner. The absence of a universal cure, the lack of treatment devoid of severe side effects and the fact that many people at risk have low awareness and knowledge about the disease all contribute to making SCD a very significant health issue for all who are at risk of the disease.

There have been more than 100 years of research to find a cure for SCD, but so far there is no universally accepted cure without side effects. Available literatures on SCD indicate that treatment protocols range from medications to gene therapy and all have one side effect or another $[1,14,15]$. This work was aimed at determining the prevalence of Sickle Cell Anemia among patients attending Immunogenetic Diagnostic Laboratory Akwanga, Nasarawa State with the view to evaluating the knowledge of the people about Sickle Cell Disease, the awareness level of pre-marital Sickle Cell Screening and the prevalence in relation to gender.

\section{Materials and Method}

\subsection{Study Area}

Akwanga is a Local Government Area in Nasarawa State. It has an area of $996 \mathrm{~km}^{2}$ and a population of 113,430 at the 2006 population census. The city is located on latitude $08^{\circ} 55^{\prime} \mathrm{N}$ and longitude $08^{\circ} 23^{\prime} \mathrm{E}$ [16].

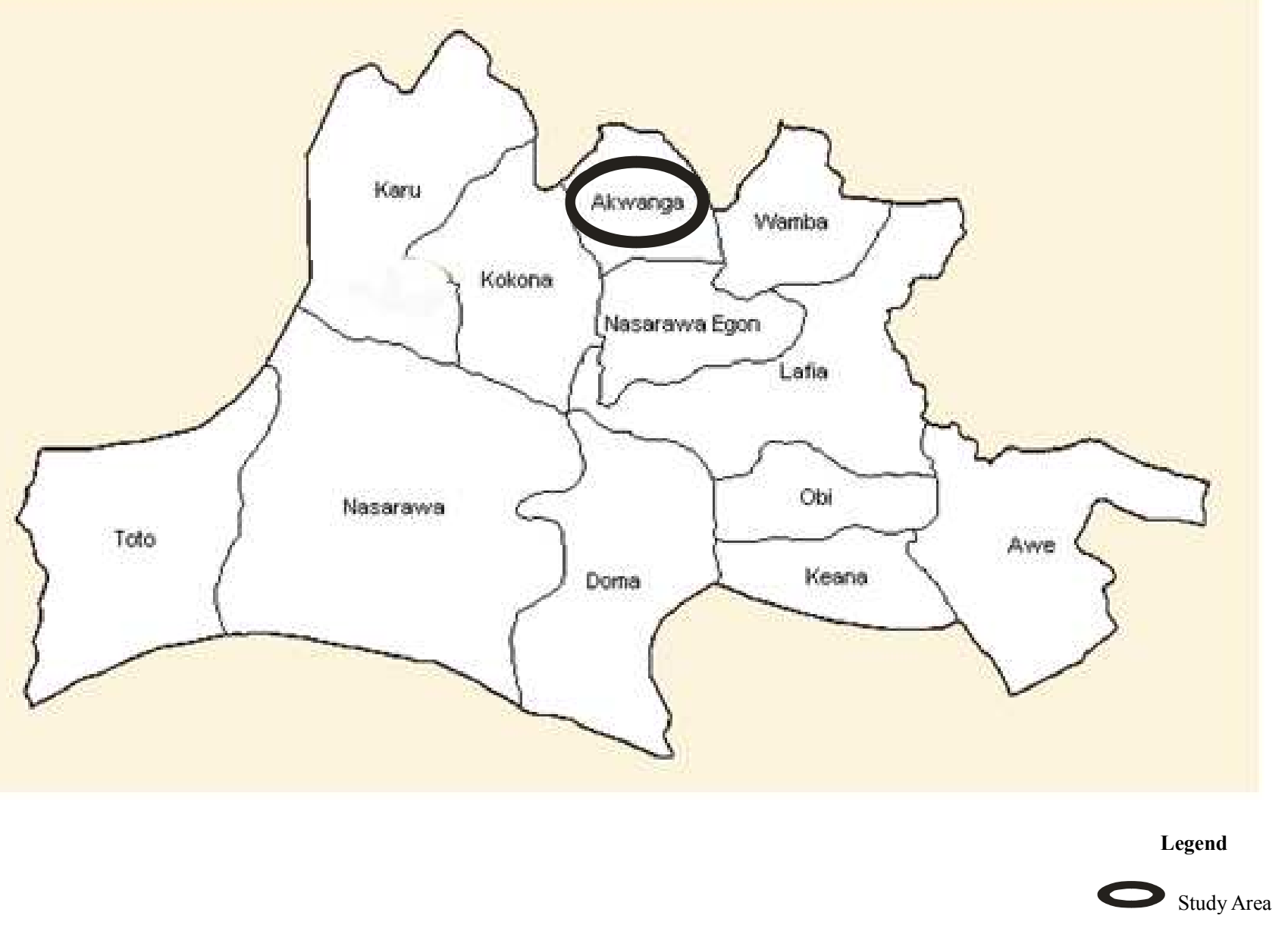

Source: [17].

Figure 1. Map of Nasarawa State Showing Study Area. 


\subsection{Sample Size}

A total of 383 patients were examined for sickle cell in this research work. This sample size was determined using the formula below.

$$
\text { Sample Size }=\frac{384.16 \times \text { Population }}{384.16+\text { Population }-1}=\frac{384.16 \times 113430}{384.16+113430-1}=\frac{43575269}{113813.6}==382.86=383
$$

Patients attending Immunogenetic Diagnostic Laboratory Centre were the patients of concern. This included patients from the major regions of Akwanga Local Government Nasarawa State. These major regions include; Akpumushi, Andaha, Alushi, Azikili, Keffi Bye-Pass, Lafia Road, Mopol base, Gbunkpau, Wambakurmi, Kibeh MCA Rimi and KurminTagwaye.

\subsection{Sample Collection}

This study lasted for a period of three months. Aseptically, $2 \mathrm{mls}$ of blood was collected using a syringe from the dorsal vein of the patients into Ethylene Diamine Tetra-acetic Acid (EDTA) bottle and mixed gently to prevent clotting. Samples were collected during working hours of the Laboratory and stored in Ethylene Diamine Tetra-acetic Acid (EDTA) bottles. This was stored pending when the blood will be examined for sickle cell. Sample bottles were correctly labeled with patient's name and laboratory number to avoid confusion in sorting out patient's results.

Well-structured questionnaires were administered to the patients involved in this study so as to obtain demographic and other relevant information regarding the research. Such information included age, gender, marital status, knowledge of pre-marital screening, knowledge of sickle cell disease etc.

\subsection{Hemoglobin Electrophoresis}

The method described by Brown (1993) was used for hemoglobin electrophoresis. A small quantity of haemolysate of venous blood from each of the subjects was placed on a cellulose acetate membrane and carefully introduced into the Electrophoretic tank containing Tris-EDTA-borate buffer at $\mathrm{pH}$ 8.6. Electrophoretic separation was then allowed to take place for 15-20 minutes at an electromotive force (Emf) of $160 \mathrm{~V}$. The results were read immediately. Haemolysate from blood samples of known hemoglobin (AS) were run as controls.

\subsection{Principle of Genotype Testing}

Charged particles under the influence of a liquid media placed in an electric field will migrate to the el;ectrode of the opposite charge. Positive ions (cations) will migrate to the cathode, the negative electrode. Negative ions (anions) will migrate to the anode, the positive electrode. At alkaline $\mathrm{pH}$ (8.6), haemoglobin is a negatively charged molecule and will migrate towards the anode $(+)$ when subjected to electrophoresis. The various haemoglobins move at different rates depending on their net negative charge.

\subsection{Data Analysis}

The percentage prevalence (\%) was calculated in each case. The results obtained were subjected to statistical package for social science version 20.0 and comparative analysis of the results were done using chi square $\left(\chi_{\chi}^{2}\right)$. A p-value less than 0.05 $(p<0.05)$ was considered statistically significant.

\section{Results}

In this study, a total of 383 patients attending Immunogenetic Diagnostic Laboratory were tested to determine the prevalence of Sickle Cell in Akwanga Local Government Area of Nasarawa State. The prevalence of Sickle Cell in relation to gender, age, locality, blood group and knowledge of premarital screening were ascertained and is presented in tables and charts below.

\subsection{Distribution of Hemoglobin Variants Among Patients}

As presented in figure 2, the hemoglobin electrophoretic pattern showed that out of 383 patients, $277(72.32 \%)$ were HbAA, 96(25.06\%) were $\mathrm{HbAS}$ and $10(2.61 \%)$ were $\mathrm{HbSS}$ respectively. HbAA has the highest prevalence while HbSS has the lowest prevalence.

\subsection{Distribution of Sickle Cell Based on Gender}

Table 1 shows the distribution of sickle cell based on gender and from this result, the prevalence of HbSS was higher in female patients $(2.1 \%)$ compared to male patients $(0.5 \%)$. The reason for this female gender susceptibility for abnormal haemoglobin gene is however unknown. The result shows that $\mathrm{p}<0.05$ thus, it is statistically significant. This means that there is a significant relationship between the prevalence of sickle cell and gender.

\subsection{Evaluation of Prevalence on the Basis of Age Group}

Figure 3, shows the evaluation of Prevalence on the basis of age group, $\mathrm{HbSS}$ was highest in the age group of 16-20 years with a $1.04 \%$ prevalence. This age group accounts for $40.0 \%$ of the total number of sickle patients observed from this study. Age groups 0-5, 11-15 and 21-25 accounted for the remaining $60 \%$ of the total population of sickle cell observed in this research work. None of the 181 patients above the age of 26 years screened for sickle cell was found to be positive. This could possibly be attributed to the fact that majority of the children with this disease die before reaching maturity. There was a significant difference observed between the prevalence of sickle cell and age. This is because $\mathrm{p}$ is less than 0.05 . 


\subsection{Distribution of Sickle Cell Disease Based on Localities}

Table 2 shows the distribution of Sickle Cell Disease based on localities and Alushi has the highest prevalence (1.6\%) of sickle cell patients in Akwanga Local Government Area of Nasarawa State. From this study it can also be concluded that about $9.4 \%$ of the people living in Alushi are positive for Sickle Cell and this accounts for a massive $60 \%$ of the total number of people living with Sickle Cell in Akwanga. WambaKurmi and Andaha make up the remaining 40\% of the sickle cell population in Akwanga. The p-value (0.043) indicates a significant relationship between locality and the prevalence of Sickle Cell Disease.

\subsection{Prevalence of Sickle Cell in Relation to the Knowledge of Pre-Marital Screening}

Prevalence of sickle cell in relation to the knowledge of pre-marital screening as presented in Figure 4 shows that a total of $182(47.5 \%)$ patients out of the 383 patients sampled had knowledge of pre-marital screening. This is slightly lower compared to the $201(52.5 \%)$ patients who had no knowledge of pre-marital screening. However, of the 10 sickle cell patients observed from this study, $6(1.6 \%)$ had a knowledge of premarital screening while 4 (1.0\%) did not. There is no significant relationship between the prevalence of sickle cell and the knowledge of pre-marital screening as $p$ $(0.423)$ is greater than 0.05 .

\subsection{Knowledge of Sickle Cell in Relation to Its Prevalence}

Knowledge of sickle cell in relation to its prevalence as presented in Table 3 showed that 8 patients $(2.10 \%)$ among the total of 10 that had SS Genotype had knowledge of sickle cell while $2(0.50 \%)$ had no knowledge of the disease. Statistically there was no significant difference $(\mathrm{P}=0.559)$ with reference of the knowledge of sickle cell in relation to its prevalence.

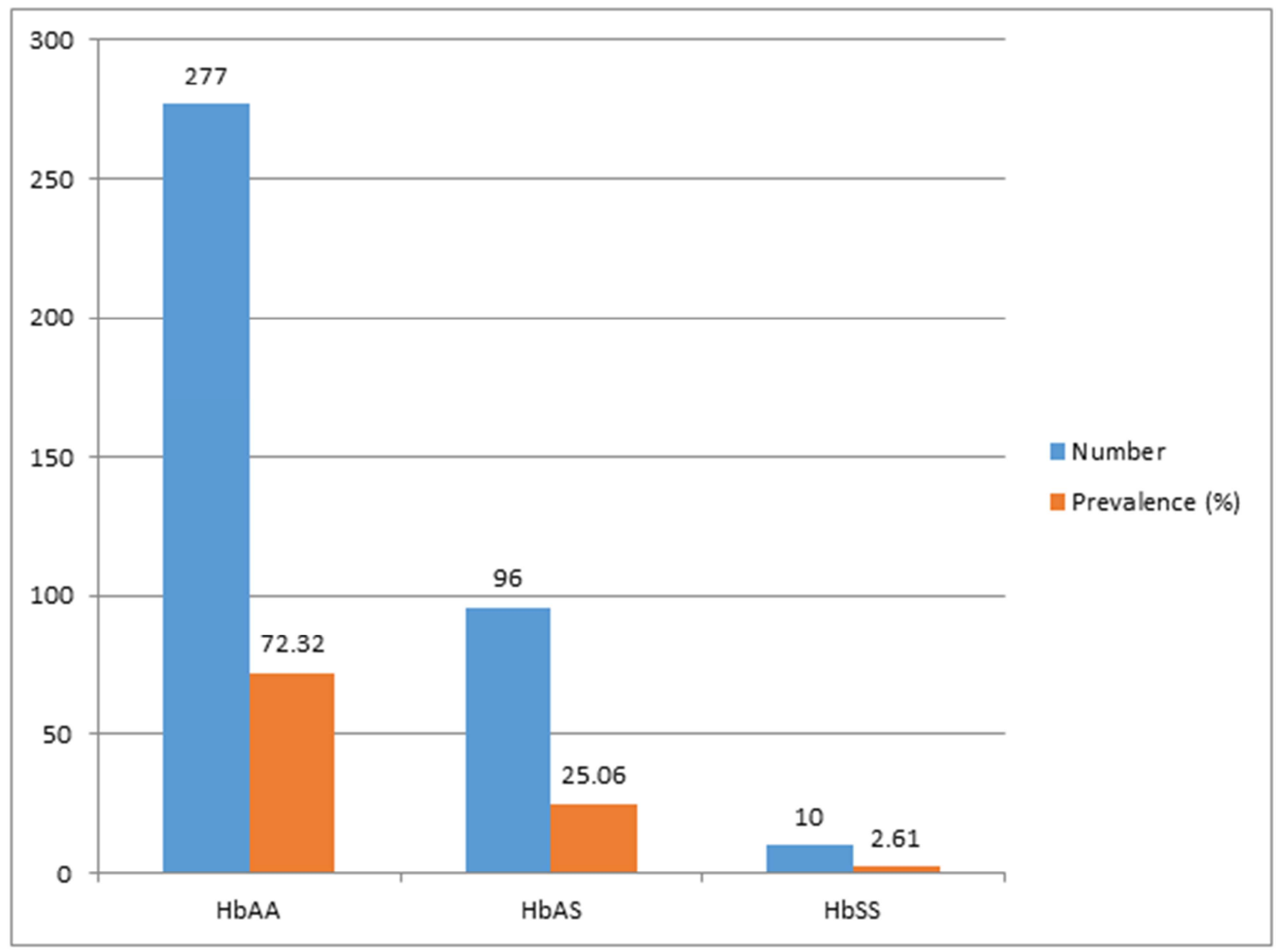

Figure 2. Distribution of Hemoglobin Variants Among Patients in Akwanga, Nasarawa State.

Table 1. Distribution of Sickle Cell Based on Gender.

\begin{tabular}{llll}
\hline Gender & Number examined & SS Genotype & P \\
\hline Male & 195 & $2(0.5 \%)$ & $\mathbf{0 . 0 4 8}$ \\
Female & 188 & $8(2.1 \%)$ & \\
Total & 383 & $10(2.6 \%)$ & \\
\hline
\end{tabular}

$\chi^{2=3.926, p<0.05}$ 


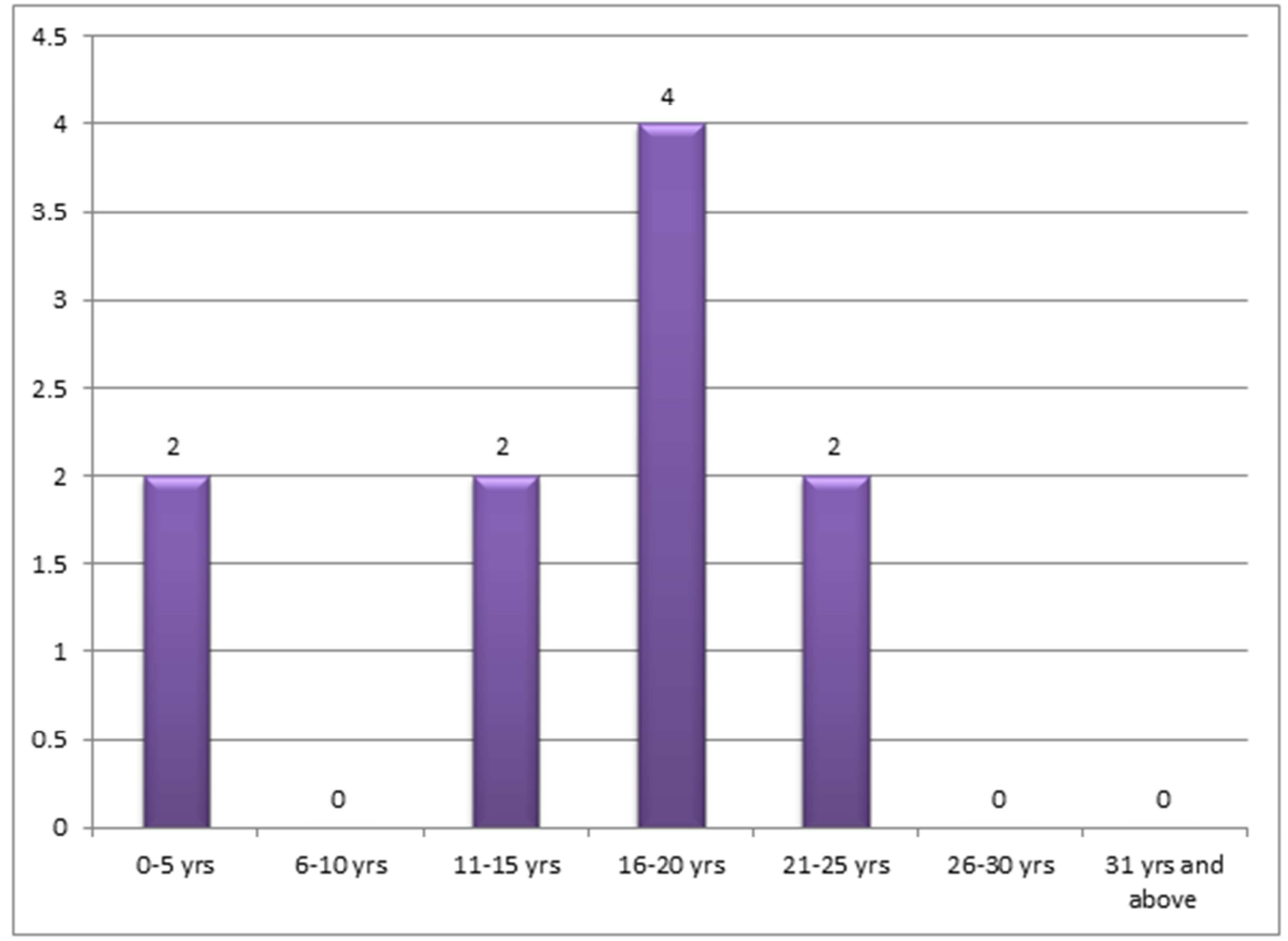

$$
\chi^{2}=26.946, \mathrm{P}=0.000(\mathrm{p}<0.05)
$$

Figure 3. Prevalence of Sickle Cell in Relation to Age.

Table 2. Sickle Cell Distribution by Localities.

\begin{tabular}{lll}
\hline Location & Sickle Cell Positive & Number examined \\
\hline Akpumushi & $0(0.00 \%)$ & 24 \\
Alushi & $6(1.60 \%)$ & 64 \\
Andaha & $2(0.50 \%)$ & 54 \\
Azikili & $0(0.00 \%)$ & 25 \\
Gbunkpau & $0(0.00 \%)$ & 12 \\
Keffi Bye Pass & $0(0.00 \%)$ & 39 \\
Kibeh MCA Rimi & $0(0.00 \%)$ & 17 \\
KurminTagwaye & $0(0.00 \%)$ & 28 \\
Lafia Road & $0(0.00 \%)$ & 43 \\
Mopol Base & $0(0.00 \%)$ & 38 \\
WambaKurmi & $2(0.50 \%)$ & 37 \\
Total & $10(2.60 \%)$ & 383 \\
\hline
\end{tabular}

$\chi^{2}=18.800, \mathrm{p}<0.05$

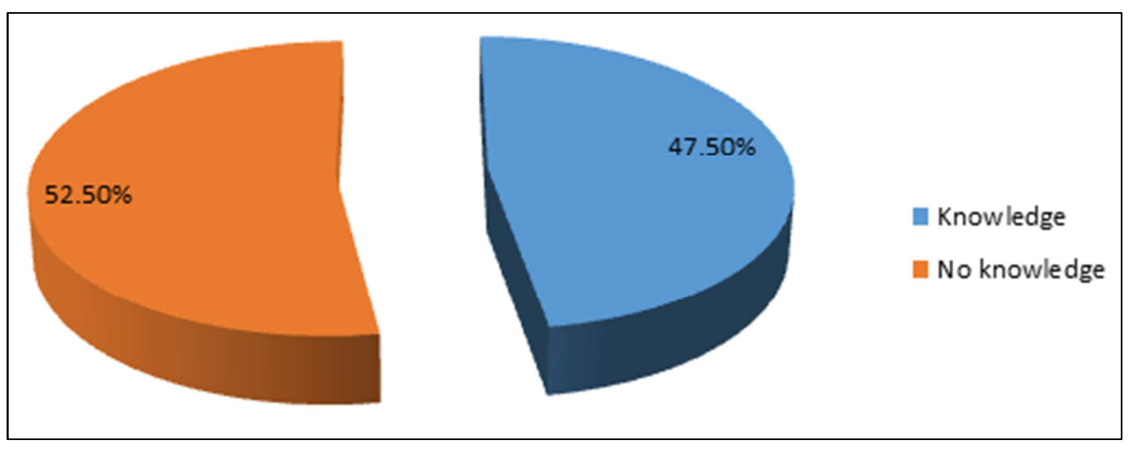

$\chi^{2}=0.641, \mathrm{P}=0.423(\mathrm{p}>0.05)$

Figure 4. Prevalence of Sickle Cell in Relation to Knowledge of Pre-Marital Screening. 
Table 3. Knowledge of Sickle Cell in Relation to Its Prevalence.

\begin{tabular}{llll}
\hline & Knowledge & No knowledge & Total \\
\hline Number Examined & 275 & 108 & 383 \\
SS Genotype & 8 & 2 & 10 \\
Prevalence & $2.10 \%$ & $0.50 \%$ & $2.60 \%$ \\
\hline
\end{tabular}

$\chi^{2}=3.41, \mathrm{P}=0.559(\mathrm{p}>0.05)$.

\section{Discussion}

Haemoglobin genotypes are inherited blood characters. In this study, a total of 383 patients were subjected to sickle cell screening over a period of three months. From this research, the prevalence of Sickle Cell Trait (AS) observed (25.06\%) is similar to the findings of [18] who reported $23.5 \%$ in Ekiti State Nigeria, [7] who also reported a prevalence of $22.19 \%$ in Ogbomosho. It is also consistent with the reports of [19, $20]$ that indicated a $20-30 \%$ prevalence rate in Nigeria. This prevalence rate is also similar to other findings by $[21,22$, $15,23,1]$ who observed a prevalence of $20-40 \%$ for Africa in general.

The prevalence of HbSS in this study is $10(2.6 \%)$ and this value is within the published value for Africa which is $1-10 \%$ [18]. This prevalence is also consistent with the findings of $[24,25$, ] who reported a prevalence rate of $2 \%$ and $3 \%$ respectively. However, this is in contrast with the findings of $[15,13]$ who reported $0 \%$ and $5.5 \%$ respectively. The low prevalence of HbSS observed in this study could be attributed to increased awareness of the disease, improved pre-marital counseling, environmental and genetic factor which have an overall effect on the sickling gene pool.

It is also observed from this study that $80 \%$ of the patients with $\mathrm{HbSS}$ were either 20 years of age or less. This age range is similar to the findings of [26] in Brazil who also reported a sickle cell prevalent rate consistent with age range of $20-29$ years. Sickle Cell Disease ultimately results in multiple organ failure and pre-mature death occurring mostly in children under five years and adolescents [11]. However, this disagrees with the findings of [27, 4] who reported $94.4 \%$ and $100 \%$ for the same age group. The overall mortality associated with Sickle Cell Disease is increased and life expectancy decreased when compared to the general population $[28,6]$. Sickle Cell Anaemia survival to adulthood in Africa was reported to be around $10-15 \%$ in the first decade of life, with the death rate of about $5 \%$ during subsequent decades $[29,30]$. The prevalence of Sickle Cell in relation to age is significant since $\mathrm{P}=0.000$; this is expected as most sickle cell patients die before reaching the age of maturity.

A sickle cell gender associated risk was observed from this research work. Females accounted for 8 (2.1\%) out of 10 patients that tested positive for sickle cell while the remaining $2(0.5 \%)$ that had sickle cell detected were male patients. Though the reason for this female gender susceptibility is unknown, it is a strong pointer to increased effort on the part of both parents and health workers to sensitize the public especially the female folks on the need to engage more in genetic counseling before marriage. This agrees with findings of [20] who reported $100 \% \mathrm{HbSS}$ in females against $0 \%$ in males. However, a disparity between the prevalence recorded in this research work with that of [10] who reported $62.96 \%$ for males and $37.04 \%$ for females at Babcock University, Ogun State, Nigeria. This research also differs from the findings from other parts of the world in India where [31] reported higher prevalence of Sickle cell in males $30(7.3 \%)$ than in females $19(5.9 \%)$ and attributed this to habits like tobacco/ghutka chewing and smoking in males. Distribution of Sickle cell disease based on locality showed that Alushi (1.6\%) accounted for $60 \%$ of sickle cell patients in Akwanga local government area. This is slightly higher than the $0.8 \%$ reported by [32] in Sudan. This high percentage rate could be attributed to migration of people from different parts of Nasarawa to Alushi local government.

Knowledge of pre-marital screening in relation to sickle cell disease showed that $47.5 \%$ had knowledge of pre marital screening while $52.5 \%$ had no prior knowledge of pre - marital screening. This percentage of knowledge about pre - marital screening for sickle cell slightly varies with the $50.7 \%$ reported by [33] but it however differs from the $100 \%$ reported by $[34,35]$ for a Semi-Urban Community in South-South Nigeria and attributed this to the fact that majority of the respondents had tertiary education and as such were knowledgeable about sickle cell disease. With respect to knowledge of sickle cell disease, 8 $(2.10 \%)$ of the patients that tested positive for sickle cell had knowledge about the disease while $2(0.50 \%)$ did not have any idea about the disease. The percentage of patients that had knowledge about the disease differs from the findings of $[34,36]$ in South South area and Benin City of Nigeria, where they reported a higher percentage of $84.3 \%$ and $17.8 \%$ respectively. It also differs from the report of [37] from Tamele city in Ghana with a $94.2 \%$ awareness of sickle cell disease.

\section{Conclusion}

The rate of prevalence recorded for $\mathrm{HbSS}$ in this study is low compared to the value range of $1-10 \%$ expected for Africa. This can be attributed to improved pre-marital counseling, increased awareness of the disease and better environmental factors. Even though sickle cell is not gender affiliated, more females had sickle cell anaemia compared to males. Sickle cell anaemia was highest in the age group of 16-20 years and Alushi had the highest prevalence of the disease based on location. Knowledge of pre-marital screening among sampled patients was low as obtained from this study. However, awareness level about sickle anaemia was high. 


\section{Appendix}

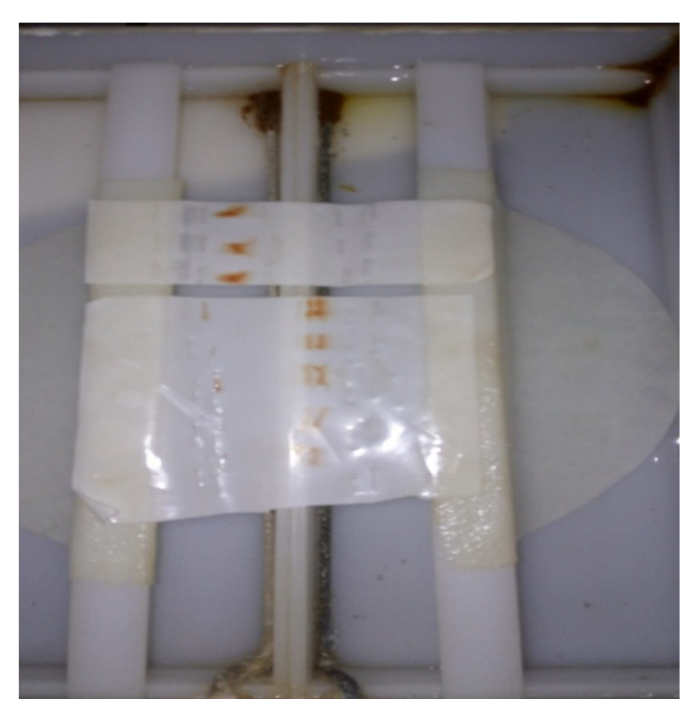

Figure 5. $H b A A$.

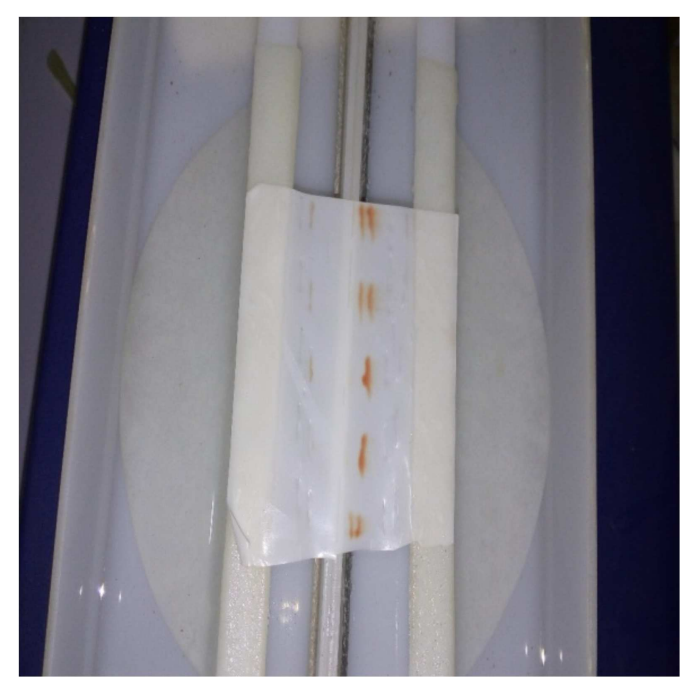

Figure 6. HbSS.

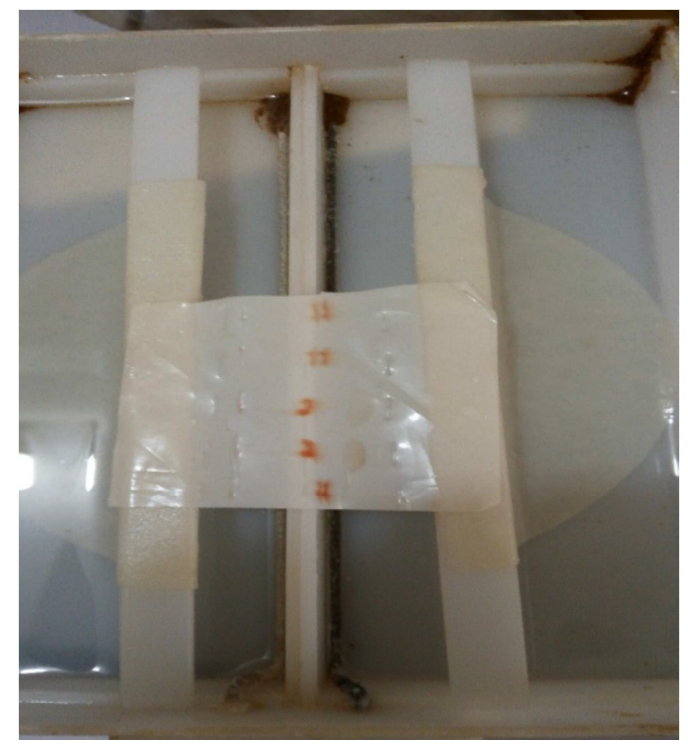

Figure 7. $H b A S$.

\section{References}

[1] A. Bakare, M. Azeez, and J., Agbolade. Gene frequency of $\mathrm{ABO}$ and Rhesus blood groups and haemoglobin variants in Ogbomosho, South West, Nigeria. Global Journal of Medical Science, 3(6):17-22. 2004.

[2] J. Boyd, A. Watkins, C. Price and M. Debaun. Inadequate community knowledge about sickle cell disease among African-American women. Journal of the National Medical Association, 97(1):63-67. 2005.

[3] P. Frenette, and G. Atweh. Sickle disease: old discoveries, new concepts, and future promise. Journal of Clinical Investigation, 117(4):850-858. 2007.

[4] O. Mustapha and F. Abubakar. Study of the prevalence of Sickle Cell Disease in Kano metropolis and its suburbs in Northern Nigeria. Nigerian Journal of Basic and Applied Science, 10(13):219-225. 2001.

[5] A. Grant, C. Parker, L. Jordan, M. Hulihan M. Creary and M. Lloyd. Public health implications of sickle cell trait: A report of the CDC meeting. American Journal of preventive Medicine, 41(4):435-439. 2011.

[6] S. Miller, L. Sleeper, C. Pegelow, L. Enos, W. Wang, S., Weiner, D. A., Wethers, J. Smith, and T. Kinny. Prediction of adverse outcomes in children with sickle cell disease. New English Journal of Medicine, 34(2):83-89. 2000.

[7] R. Akhigbe, Ige, A. Afolabi, O., Azeez, G., Adegunlola, and J. Bamidele. Prevalence of haemoglobin variants, $\mathrm{ABO}$ and Rhesus blood groups in Ladoke Akintola University of Technology, Ogbomosho, Nigeria. Trends in Medical Research, 4(2):24-29. 2009.

[8] I. Oluwadare, and S. Shonekan. ABO and Rhesus blood type distribution in students admitted into Moshood Abiola Polytechnic Abeokuta, Nigeria. African Journalof Biotechnology, 7(1):1641-1643. 2006.

[9] K. Acharya, C. Lang and L. Ross. A pilot study to explore knowledge, attitudes, and beliefs about sickle cell trait and disease. Journal of the National Medical Association, 10(11):1143-1172. 2009.

[10] A. Adeyemi, O. Ladipo, D. Omolade and A. Ogbaro. Frequency of distribution of Haemoglobin Variants among teenagers. British Journal of Medicine and Biomedical Research, 14(4):1-5. 2016.

[11] M. Creary, D. Williamson and R. Kulkarni. Sickle cell disease report: current activities, public health implications and future directions. Journal of women's health, 16(3):575-582. 2007.

[12] E. Abioye, O. Oyegbade, I. Bello and C. Osakwe. Sickle cell knowledge, premarital screening and marital decisions among local government workers in Ile Ife, Nigeria. Journal of Rural Health, 16 (1):43-49. 2009.

[13] P. Ozoegwu and A. Onwurah. Prevalence of haemoglobinopathy and Malaria disease in the population of old Aguata division, Anambra State, Nigeria. Biokemistri, 15(9):57-66. 2003.

[14] S. Lanzkron, J. Strouse, R. Wilson, M. Beach, C. Haywood and H. Park. Systematic reiew: hydroxyurea for the treatment of adults with sickle cell disease. Annual International Medicine, 148(12):939-955. 2008. 
[15] Z. Jeremiah. Abnormal haemoglobin variants, $A B O$ and Rhesus blood groups among students of African descent in Port Harcourt, Nigeria. African Health Science, 6(3):177-181. 2006.

[16] http://en.m.wikipedia.org/wiki/Akwanga. Retrieved $10^{\text {th }}$ August 2017.

[17] http://www.nasarawastate.gov.ng. Retrieved on $2^{\text {nd }}$ October 2017.

[18] A. Esan, C. Omisakin, and D. Okhuakhua. Frequency distribution of haemoglobin variant, $\mathrm{ABO}$ and Rhesus blood group distribution among children in Ido/Osi Local Government, Ekiti State Nigeria. Journal of Medical Laboratory Science, 21(2):58-61. 2012.

[19] N. Thomas, O. Ernest, I. Nkoyo, and A. Rahman. Frequency of haemoglobin variants among Yorubas in Ibadan, South Western Nigeria: A Pilot study. Nigerian Journal of Experimental Clinical Biological Science, 1(4):39-42. 2013.

[20] E. Adu, C. Isibor, and E. Ezie. Prevalence of haemoglobin variants among the Ika ethnic nationality of Delta State. International Journal of Medicine and Medicine and Biomedical Research, 3(2):63-67. 2014.

[21] O. Erhabor, T. Adias, Z. Jeremiah and M. Hart. Abnormal haemoglobin variants, $\mathrm{ABO}$, and Rhesus blood group distribution among students in the Niger Delta of Nigeria. Pathology and Laboratory Medicine International, 2(7):41-46. 2010.

[22] G. Pennap, E. Envoh, and I. Igbawua. Frequency distribution of haemoglobin variants, $\mathrm{ABO}$ and Rhesus blood groups among students of African descent. British Microbiology Journal, 1(2):33-40. 2011.

[23] B. Mondal, S. Maiti, B. Biswas, D. Ghosh and S. Paul. Prevalenc of haemoglobinopathy, $\mathrm{ABO}$ and Rhesus blood groups in rural areas of West Bengal, India. Journal of Research Medical Science, 17(3):772-776. 2012.

[24] U. Egesie, O. Egesie, I. Usar and T. Johnbull. Distribution of $\mathrm{ABO}$, Rhesus blood and haemoblobin electrophoresis among the undergraduate students of Niger Delta University, Nigeria. Nigerian Journal of Physiological Science, 23(4):5-8. 2008.

[25] A. Nwafor and B. Banigo. A comparison of measured and predicted haemoglobin genotype in a Nigerian population in Bonny, Rivers State, Nigeria. Journal of Applied and Environmental Managements, 5(7):79-81. 2001.

[26] P. G. Sant'Ana, A. M. Araujo, C. T. Pimenta, M. L. Bezerra, S. P. Junior, V.M.Neto, J.S.Dias, A. F.Lopes, D.R. Alves, M. Pinheiro. Clinical and laboratory Profile of Patients with Sickle Cell Anemia. Brazilian Journal of Hematology and Hemotherapy. 39(1):40-4. 2017.

[27] A. Yakubu, L. Zama, B. Sanusi, P. Frank, A. Ezimah and W.
Abdullahi. Haemoglobin electrophoretic pattern among residents in Sokoto, Nigeria. Journal of Medical Disorders, 3(6):1-5. 2012.

[28] D. Powers, D. Elliot, L. Chan, J. Niland, A. Hiti, L. Opas and C. Johnson. Chronic renal failure in sickle cell disease: risk factors, clinical course and mortality. Annual International Medicine, 115(17):614-620. 1991.

[29] I. Odame. Developing a global agenda for sickle cell disease: report of an international symposium and workshop in Cotonou, Republic of Benin. American Journal of Preventive Medicine, 3(8):571-573. 2010.

[30] L. Tshilolo, E. Kafando, M. Sawadogo, F. Cotton, F. Vertoghen, A. Ferster and B. Gulbis. Neonatal screening and clinical care programmes for sickle cell disorders in subsaharan Africa: lessons from pilot studies. Public Health, 122(23):933-941. 2008.

[31] C. V. Akre, N. D. Sukhsohale, S. S. Kubde, S. B. Agrawal, M. B. Khamgaokar, S. M. Chaudhary, M. A. Dhoble. Do gender differences influence the prevalence of sickle cell disorder and related morbidities among school children in rural central India? International Journal of Collaborative Research on Internal Medicine \& Public Health. 5 (5): 348 - 358. 2013.

[32] M. M. Sabahelzain and H. Hamamy. The ethnic distribution of sickle cell disease in Sudan. The Pan African Medical Journal. 2014; 8: 13. doi:10.11604/pamj.2014.18.13.3280. 2014.

[33] E. A. Oyedele, A. Emmanuel, L. D. Gaji, D. E. Ahure. Awareness and acceptance of premarital genotype screening among youths in a Nigerian community. International Journal of Medical and Health Research 1(1): 17-21. 2015.

[34] K. G. Precious, F. B. Seiyefa, O. Best. Knowledge, Attitude and Uptake of Premarital Screening for the Sickle Trait Among Married Couples in a Semi-Urban Community in South-South Nigeria. European Journal of Preventive Medicine. 3(3): 49-54. 2015.N. I. Ugwu. Sickle cell disease: Awareness, knowledge and attitude among undergraduate students of a Nigerian tertiary educational institution. Asian Journal of Medical Sciences. 7 (5): 87 - 92. 2016.

[36] A. S. Adewoyin, A. E. Alagbe, B. O. Adedokun, and N. T. Idubor. Knowledge, Attitude and Control Practices Of Sickle Cell Disease among Youth Corps Members in Benin City, Nigeria. Annals of Ibadan Postgraduate Medicine. 13(2): 3542. 2015.

[37] E. P. Ameade, B. S. Mohammed, G. K. Helegbe, S. Yakubu. Sickle Cell Gene Transmission: Do Public Servants in Tamale, Ghana Have the Right Knowledge and Attitude to Curb It? Open Journal of Preventive Medicine, 2015 (5): 299-308. 2015. 